\title{
Sheep Gastric Mucins as a Source of Blood-Group-I and -i Antigens
}

\author{
Edwin WOOD, Elizabeth F. HOUNSELL, Jean LANGHORNE and Ten FEIZI \\ Division of Communicable Diseases, Clinical Research Centre, Watford Road, Harrow, \\ MiddX. HA1 3UJ, U.K.
}

(Received 17 December 1979)

\begin{abstract}
Gastric-mucosal glycoproteins of sheep have been shown to express the blood-group-I and $-\mathrm{i}$ antigens. The highest blood-group-I activities were found in glycoproteins lacking in blood-group-A and -H activities. In antigenically very active glycoprotein preparations, approx. $25 \%$ of the macromolecules expressed various blood-group-I and $-i$ antigens, and these could be enriched by affinity chromatography with an anti-(blood group I) immunoadsorbent column. Additional blood-group-I and -i activities could be revealed by one cycle of Smith degradation of blood-group-A-active sheep gastric glycoproteins. Thus sheep gastric mucins are an abundant source of oligosaccharides with blood-group-I- and -i-active sequences.
\end{abstract}

Mucins obtained from human ovarian-cyst fluids and from animal gastric mucosae have been invaluable sources of blood-group antigens for immunochemical and structural studies (Kabat, 1970; Watkins, 1974). Knowledge of the antigenic determinants involved in the blood-group-A, -B, - H, -Lewis $^{a}\left(L^{a}\right)$ and - Lewis $^{b}\left(L^{b}\right)$ antigens were largely acquired through studies of oligosaccharides released from these glycoproteins. The finding of blood-group-I and -i activities on such glycoproteins lacking in blood-group- $\mathrm{A},-\mathrm{B}$ and $-\mathrm{H}$ activities provided the first clue that the blood-group-I and -i antigens were expressed on oligosaccharide precursors of the blood-group-A, -B and $-\mathrm{H}$ antigens (Feizi et al., 1971a), and it was readily demonstrated that the monoclonal anti-(blood group I) antibody of one donor (Ma) could be specifically inhibited by the oligosaccharide sequence $\mathrm{Gal} \beta 1 \rightarrow 4$ GlcNAc $\beta 1 \rightarrow 6$ - (Feizi et al., 1971b). This oligosaccharide sequence occurs on branched precursor chains of blood-groups-ABH-active secreted glycoproteins (Lloyd et al., 1968) and erythrocyte glycosphingolipids (Hakomori et al., 1972). However, it was apparent that the antigenic determinants recognized by the anti-(blood group I) antibodies of the majority of other patients and by anti-(blood group i) antibodies were different (Feizi \& Kabat, 1972), for they were not inhibited by the above oligosaccharide sequence, nor were they inhibited by the precursor chain isomer Gal $\beta 1 \rightarrow 3 \mathrm{GlcNAc} \beta 1 \rightarrow 3$ (which commonly occurs on secreted human glycoproteins). However, the limited amounts of purified oligosaccharides precluded assays at high concentrations of inhibitor. Recent studies on purified glycosphingolipids derived from human and bovine erythrocyte membranes have shown that lacto$N$-norhexaosylceramide,

$$
\begin{aligned}
& \mathrm{Gal} \beta 1 \rightarrow 4 \mathrm{GlcNAc} \beta 1 \rightarrow 3 \mathrm{Gal} \beta 1 \rightarrow 4 \mathrm{GlcNAc} \beta 1 \rightarrow \\
& 3 \mathrm{Gal} \beta 1 \rightarrow 4 \mathrm{Glc} \beta \rightarrow \mathrm{Cer}
\end{aligned}
$$

when incorporated into cholesterol/phosphatidylcholine micelles, is a potent inhibitor of the majority of anti-(blood group i) antibodies (Niemann et al., 1978) and that the related branched structure, lacto- $N$-isooctaosylceramide:

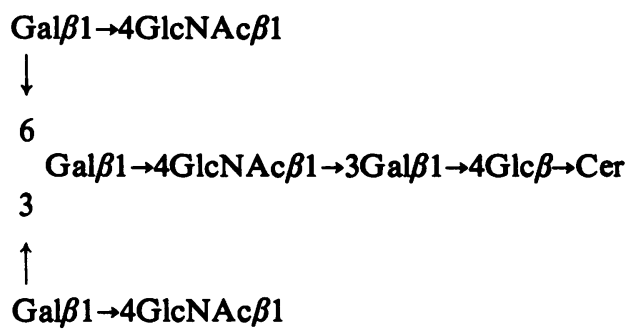


reacts with the majority of anti-(blood group I) antibodies (Watanabe et al., 1979; Feizi et al., 1979). Three types of anti-(blood group I) specificities could be distinguished, those reactive with the $1 \rightarrow 4,1 \rightarrow 6$ branch, those recognizing the $1 \rightarrow 4,1 \rightarrow 3$ branch and those requiring both branches to be intact.

All these studies thus far have implicated Gal $\beta 1 \rightarrow 4$ GlcNAc-(type- 2 chain)-containing structures rather than $\mathrm{Gal} \beta 1 \rightarrow 3 \mathrm{GlcNAc}$-(type-1 chain)containing structures in blood-group-I and $-i$ specificities. Radioimmunoassays of synthetic di-, tri-, tetra- and penta-saccharides containing type-1 and type- 2 chains have confirmed these observations (Wood \& Feizi, 1979). However, the very large amounts of these oligosaccharides required to give inhibition are in support of previous suggestions that the antigenic determinants recognized by the majority of anti-(blood group I and i) antibodies are longer than trisaccharide. Thus it was of interest to determine precisely the size and structures of the various blood-group-I and -i antigenic determinants by studying oligosaccharides of varying length derived from glycoproteins. With the availability of radioimmunoassay (Wood et al., 1979), it is now feasible to screen oligosaccharides released from glycoproteins for blood-group-I and -i activities and to select antigenically active fractions for purification and structural studies. In the course of antigenic analyses of secreted glycoproteins of human and animal origins for abundant sources of blood-group-I- and -i-active oligosaccharides, we observed that the gastric mucins of certain sheep expressed these antigens strongly. The present paper describes the blood-group-I, -i, - $A$ and $-\mathrm{H}$ activities of sheep gastric glycoproteins before and after one cycle of Smith degradation. It is shown that, even in antigenically very active glycoprotein preparations, the blood-group-I and $-\mathrm{i}$ antigens are expressed on only a subpopulation of macromolecules, and these can be specifically enriched by affinity chromatography with an anti-(blood group I) adsorbent column.

\section{Materials and Methods}

\section{Preparation of glycoprotein extracts from stomach mucosae}

Fresh adult sheep stomachs (abomasa) were obtained at slaughter from a local abattoir. Glycoprotein-rich extracts of the mucosal scrapings from individual stomachs were prepared after digestion with pepsin as described previously (Bendich et al., 1946; Feizi et al., 1975). Aqueous solutions thus obtained were extracted twice with 2 vol. of chloroform/methanol $(2: 1, \mathrm{v} / \mathrm{v})$ to remove lipids. A total of 17 individual mucosae were processed in two batches and were designated S1-S12 and S13-S17; the yields of glycoprotein ranged from 1.4 to $3.9 \mathrm{mg} / \mathrm{g}$ wet wt. of mucosa $(160-460 \mathrm{mg}$ dry weight of extract/mucosal sample).

\section{Monosaccharide analysis}

Monosaccharide analysis of the glycoproteins was performed by g.l.c. of trimethylsilyl ethers of methyl glycosides (Bhatti et al., 1970) under the conditions described by Hounsell (1977). Samples of glycoprotein $(10-50 \mu \mathrm{g})$, with perseitol ( $\alpha$-mannoheptitol; Sigma Chemical Co., Poole, Dorset, U.K.) as internal standard, were analysed on a column of 3\% SE30 on Chromosorb WHP (Chromatography Services Ltd., Hoylake, Merseyside, U.K.) by using a Pye 204 chromatograph (Pye-Unicam Ltd., Cambridge, U.K.) and a Supergrator I integrator (Columbia Scientific Industries, Austin, TX, U.S.A.). Under the conditions of the analyses, any glucose found was considered to be a contaminant (it was also found in blank assays).

\section{Antigenic analysis of glycoproteins}

The reactivities of glycoprotein extracts with several anti-(blood groups I and i) sera of differing fine specificities obtained from different donors were measured by a double-antibody radioimmunoassay and by microquantitative precipitin assay as described previously by Wood et al. (1979) and Feizi et al. $(1971 b)$ respectively. In radioimmunoassays the results were expressed as the concentration of glycoprotein $(\mu \mathrm{g} / \mathrm{ml})$ required to give $50 \%$ inhibition of binding of an anti-[blood group I (or i)] serum to a radioiodinated blood-group-I- or -Ii-active glycoprotein. In quantitative precipitin assays the results were expressed as the amount $(\mu \mathrm{g})$ of glycoprotein required to precipitate $2 \mu \mathrm{g}$ of antibody nitrogen.

Seven anti-(blood group I) sera (Ma, Step, Low, Gra, Da, Phi and Ver) and four anti-(blood group i) sera (Tho, Den, Galli and Nic) were used. These were obtained from patients with chronic coldagglutinin disease (with their informed consent) and contain monoclonal immunoglobulin $\mathbf{M}$ antibodies that [with the exception of anti-(blood group i) (serum Galli)] have been shown to recognize antigenic determinants on branched [anti-(blood group I)] and straight-chain [anti-(blood group i)] oligosaccharide precursors of blood-groups-ABH antigens on erythrocyte glycosphingolipids (Feizi et al., 1971b, 1979; Neimann et al., 1978; Watanabe et al., 1979).

Other blood-group activities were determined by haemagglutination-inhibition assays using the microtitre technique as described previously (Feizi et al., $1971 a$ ). Eight haemagglutinating units of human immune anti-(blood group A and B) sera (Ortho Pharmaceutical Ltd., High Wycombe, Bucks., U.K.), goat anti-(blood group $\mathrm{Le}^{\mathrm{a}}$ and $\mathrm{Le}^{\mathrm{b}}$ ) sera 
[Hoechst (U.K.) Ltd., Hounslow, Middx., U.K.], rabbit anti-(blood group $M$ and $N$ ) sera [Dade (Division of American Supply Corporation), Miami, FL, U.S.A.)], anti-(blood group $P_{1}$ ) serum (Behringwerke A.G., Marburg-Lahn, Germany) and Ulex europaeus (gorse) anti-(blood group $\mathrm{H}$ ) lectin (Dade) were used with erythrocytes of appropriate blood type. For tests with the anti-(blood group $\mathrm{Le}^{\mathrm{a}}$ and $\mathrm{Le}^{\mathrm{b}}$ ) antisera, erythrocytes were washed three times with iso-osmotic saline $(0.9 \% \mathrm{NaCl})$ and the packed cells were incubated with an equal volume of a solution of ficin (Sigma Chemical Co., Poole, Dorset, U.K.) at $37^{\circ} \mathrm{C}$ for $15 \mathrm{~min}$ and washed three times with iso-osmotic saline. In haemagglutination tests with the remaining reagents, washed untreated cells were used.

\section{Smith degradation of sheep glycoproteins}

One cycle of Smith degradation was performed as described by Hammerström et al. (1975). Samples $(5 \mathrm{mg})$ of each of the glycoprotein extracts $\mathrm{S} 1, \mathrm{~S} 3$, $\mathrm{S} 5, \mathrm{~S} 11, \mathrm{~S} 12, \mathrm{~S} 14$ and $\mathrm{S} 17$ were dissolved in $5 \mathrm{ml}$ of $0.1 \mathrm{M}$-sodium acetate buffer, $\mathrm{pH} 4$, containing $8 \mathrm{~mm}$ sodium metaperiodate. After oxidation for $70 \mathrm{~h}$ in the dark at $4^{\circ} \mathrm{C}$, the samples were reduced with $5 \mathrm{mg}$ of $\mathrm{NaBH}_{4}$ for $18 \mathrm{~h}$ at $4^{\circ} \mathrm{C}$, and hydrolysed with $0.5 \mathrm{M}-\mathrm{HCl}$ at $20^{\circ} \mathrm{C}$ for $18 \mathrm{~h}$. The samples were dialysed against water between each step, centrifuged and freeze-dried.

Previous studies with blood-group substances (Lloyd \& Kabat, 1968) have indicated that one cycle of Smith degradation results in the destruction of only the terminal monosaccharides (also subterminal galactose residues in blood-group- $\mathrm{H}$ substance).Thus the following predictions would apply: terminal (non-reducing) galactose residues of precursor chains, terminal fucose and $\mathrm{N}$-acetylgalactosamine residues of blood-group-A substances, and terminal fucose residues and subterminal galactose residues of blood-group- $\mathrm{H}$ substances would be destroyed.

\section{Affinity chromatography of sheep glycoproteins}

An adsorbent made from the anti-(blood group I) antibody of patient Low was as described by Feizi et al. (1975), and contained approx. $850 \mathrm{mg}$ of antibody protein coupled to $85 \mathrm{ml}$ of Sepharose 4B. This anti-(blood group I) antibody recognizes both chains of the branched blood-group-I-active structure (Feizi et al., 1979). A pool of several sheep stomach glycoprotein extracts $(22 \mathrm{mg})$ with strong bloodgroup-I activity (as determined by quantitative precipitin assay) were dissolved in $4.5 \mathrm{ml}$ of isoosmotic saline. This solution was passed at $4^{\circ} \mathrm{C}$ with a flow rate of $4 \mathrm{ml} / \mathrm{h}$ down the adsorbent column equilibrated in iso-osmotic saline. The column was washed under gravity with $250 \mathrm{ml}$ of iso-osmotic saline at $4^{\circ} \mathrm{C}$ and eluted with $600 \mathrm{ml}$ of iso-osmotic saline at $37^{\circ} \mathrm{C}$ as described by Feizi \& Kabat (1974). The blood-group-I activity present in $10 \mu \mathrm{l}$ portions of the non-retained and eluted fractions ( $5 \mathrm{ml}$ each) was monitored by radioimmunoassay (Wood et al., 1979) with the anti-(blood group I)-antibody Step. Pools were made of the nonretained fractions [these were lacking in inhibitory activity with anti-(blood group I) Step antibody] and the blood-group-I-active eluted fractions; these were dialysed against water and freeze-dried.

\section{Results}

Occurrence of blood-group-I, $-i,-A$ and $-H$ antigens among glycoprotein extracts from individual sheep stomach mucosae

Glycoprotein extracts were obtained from 17 individual sheep stomach mucosae in two batches designated S1-S12 and S13-S17. The reactivities of these extracts in quantitative precipitin assays with six anti-(blood group I) sera of differing specificities and one anti-(blood group i) serum are shown in Table 1. The extracts were divided into two groups: those in group 1 showed precipitating activity with the majority of anti-(blood group I) sera and those in group 2 showed no precipitating activity at the highest amount tested $(50 \mu \mathrm{g})$ or reacted only with anti-(blood group I) serum Ma. None of the extracts showed precipitating activity with the anti-(blood group i) serum Galli. Four extracts from each group [S1, S2, S3 and S12 (group 1) and S5, S11, S14 and $\mathrm{S} 17$ (group 2)] were tested as inhibitors of seven anti-(blood group I) and four anti-(blood group i) sera in radioimmunoassays (Fig. 1). The strong blood-group-I activities in group 1 were confirmed; however, weak to moderate blood-group-I activity was revealed by radioimmunoassays in extracts in group 2 and some blood-group-i activity was found in six of the eight extracts tested.

The results of haemagglutination inhibition assays for blood-group-A and - $\mathrm{H}$ activity are also shown in Table 1. An inverse relationship was found between blood-group-A activities and -I activities in the extracts: there was little or no blood-group-A activity detected among the strongly blood-groupI-active extracts in group 1 , but there was strong blood-group-A activity among the extracts in group 2 with the exception of extract S5. Blood-group-H activity was variably expressed in the two groups and was lacking in the three extracts with the highest blood-group-I activities (extract S1, S2, S10). None of the glycoproteins showed blood-group-B activity at the highest concentration tested $(500 \mu \mathrm{g} / \mathrm{ml})$.

The extracts S1, S3, S5, S11, S14 and S17, representative of both groups, were tested for blood-group-Le $\mathrm{Le}^{\mathrm{a}},-\mathrm{Le}^{\mathrm{b}},-\mathrm{M},-\mathrm{N}$ and $-\mathrm{P}_{1}$ activities by haemagglutination-inhibition assays and were found 
to be inactive at the highest concentrations tested $(500 \mu \mathrm{g} / \mathrm{ml}$; results not shown).

Monosaccharide analyses of sheep gastric mucins

Monosaccharide analyses of eight of the sheep- gastric-mucin preparations showed that they contained predominantly galactose, $N$-acetylglucosamine and $N$-acetylgalactosamine (Table 2). The highest proportion of galactose was found among the mucins in group 1 , which had the strongest bloodgroup-I activities. The highest proportion of $\mathrm{N}$-acetyl-

Table 1. Blood-group-I, $-i,-A$ and $-H$ activities of sheep gastric glycoproteins assessed by quantitative precipitin or haemagglutination-inhibition assays

\begin{tabular}{|c|c|c|c|c|c|c|c|c|c|c|}
\hline & \multirow{3}{*}{$\begin{array}{r}\text { Antiserum } \ldots \\
\text { Glycoprotein }\end{array}$} & \multicolumn{7}{|c|}{$\begin{array}{l}\text { Glycoprotein required to precipitate } 2 \mu \mathrm{g} \text { of antibody } \\
\text { nitrogen }(\mu \mathrm{g})\end{array}$} & \multicolumn{2}{|c|}{$\begin{array}{l}\text { Glycoprotein } \\
\text { concentration giving } \\
\text { haemagglutination- } \\
\text { inhibition }(\mu \mathrm{g} / \mathrm{ml})\end{array}$} \\
\hline & & & & nti-(bl & group & & & $\begin{array}{c}\text { Anti- } \\
\text { (blood }\end{array}$ & Anti- & Anti- \\
\hline & & $\mathrm{Ma}$ & Step & Low & $\mathrm{Da}$ & Phi & Ver & Galli & group A) & group $\mathrm{H}$ ) \\
\hline Group 1 & $\begin{array}{l}\text { S2 } \\
\text { S1 } \\
\text { S10 } \\
\text { S3 } \\
\text { S9 } \\
\text { S12 } \\
\text { S8 } \\
\text { S6 }\end{array}$ & $\begin{array}{r}2 \\
4 \\
5 \\
14 \\
40 \\
4 \\
28 \\
56\end{array}$ & $\begin{array}{r}4 \\
7 \\
11 \\
13 \\
23 \\
27 \\
28 \\
45\end{array}$ & $\begin{array}{r}8 \\
14 \\
18 \\
44 \\
>50 \\
58 \\
58 \\
>50\end{array}$ & $\begin{array}{l}10 \\
19 \\
21 \\
\frac{44}{58}+ \\
\frac{58}{-}\end{array}$ & $\begin{array}{r}10 \\
13 \\
16 \\
22 \\
42 \\
>50 \\
48 \\
> \\
>\end{array}$ & $\begin{array}{r}19 \\
24 \\
30 \\
27 \\
>50 \\
>50 \\
48 \\
>50\end{array}$ & $\begin{array}{l}>50 * \\
>50 \\
>50 \\
>50 \\
>50 \\
>50 \\
>50 \\
>50\end{array}$ & $\begin{array}{r}125 \\
>500 \\
125 \\
62 \\
>500 \\
>500 \\
>500 \\
>500\end{array}$ & $\begin{array}{r}>500 \\
>500 \\
>500 \\
8 \\
8 \\
8 \\
62 \\
250\end{array}$ \\
\hline Group 2 & $\begin{array}{l}\text { S13 } \\
\text { S17 } \\
\text { S16 } \\
\text { S15 } \\
\text { S7 } \\
\text { S4 } \\
\text { S14 } \\
\text { S11 } \\
\text { S5 }\end{array}$ & $\begin{array}{r}5 \\
7 \\
16 \\
20 \\
25 \\
37 \\
>50 \\
>50 \\
>50\end{array}$ & $\begin{array}{l}- \\
\overline{-} \\
\overline{-} \\
>50 \\
\overline{50} \\
>50\end{array}$ & $\begin{array}{l}>50 \\
>50 \\
>50 \\
>50 \\
>50 \\
>50 \\
>50 \\
>50 \\
>50\end{array}$ & $\begin{array}{l}- \\
= \\
= \\
\overline{-} \\
-\end{array}$ & $\begin{array}{l}>50 \\
>50 \\
>50 \\
>50 \\
>50 \\
>50 \\
>50 \\
>50 \\
>50\end{array}$ & $\begin{array}{l}E \\
\overline{-} \\
>50 \\
>50 \\
\overline{50} \\
>50\end{array}$ & $\begin{array}{l}>50 \\
>50 \\
>50 \\
>50 \\
>50 \\
>50 \\
>50 \\
>50 \\
>50\end{array}$ & $\begin{array}{l}0.3 \\
0.6 \\
0.2 \\
0.2 \\
4 \\
0.5 \\
0.3 \\
2 \\
>500\end{array}$ & $\begin{array}{r}125 \\
125 \\
62 \\
500 \\
32 \\
62 \\
62 \\
62 \\
8\end{array}$ \\
\hline
\end{tabular}

* Less than $2 \mu \mathrm{g}$ of antibody nitrogen precipitated with the greatest amount of glycoprotein tested $(50 \mu \mathrm{g})$.

+ Not tested.

Table 2. Monosaccharide analysis of original and one-cycle-Smith-degraded sheep stomach glycoproteins Non-standard abbreviation used: SA, sialic acid.

Monosaccharide content (nmol/100 nmol of carbohydrate) content

Glycoprotein Monosaccharide ... $\overbrace{\text { Fuc }}$ Man Glc* Gal GlcNAc GalNAc SA $\begin{gathered}\text { (g/lycoprotein) } \\ \text { glycol }\end{gathered}$

Group 1: S2†

$\mathrm{S} 1$
$\mathrm{~S} 1 \mathrm{IO}_{4}$
$\mathrm{~S} 3$
$\mathrm{~S} \mathrm{IO}_{4}$
$\mathrm{~S} 12$
$\mathrm{~S} 12 \mathrm{IO}_{4}$

Group 2: $\$ 17$

$\mathrm{S}_{17} \mathrm{IO}_{4}$

S14

$\mathrm{S}_{14} \mathrm{IO}_{4}$

S11

$\mathrm{S}_{11} \mathrm{IO}_{4}$

S5

$\mathrm{S} \times \mathrm{IO}_{4}$

$\begin{array}{cc}1.5 & 1.0 \\ 5.4 & 0.8 \\ 0 & 0.7 \\ 10.5 & 1.2 \\ 0 & 0.8 \\ 11.1 & 1.1 \\ 0 & 1.1 \\ 11.0 & 1.3 \\ 0 & 1.3 \\ 12.4 & 1.3 \\ 0 & 0.7 \\ 4.8 & 5.0 \\ 0 & 2.6 \\ 10.1 & 1.5\end{array}$

$4.9 \quad 38.0$

$4.6 \quad 46.5$

$3.6 \quad 31.2$

$\begin{array}{ll}5.4 & 36.7\end{array}$

$0.6 \quad 32.4$

$6.5 \quad 34.4$

9.4

14.1

31.0

30.5

35.9

16.2

40.5

29.4

47.0

$19.0 \quad 4.5$

12.1

28.6

23.8

25.7

17.2

28.4

\section{7}

38.6

22.2

33.0

26.9

44.1

23.4

not analysed

25.6

23.0

30.1

31.0

21.0

20.8

$\begin{array}{ll}6.2 & 26.4\end{array}$

$5.4 \quad 29.4$

* The amounts of glucose detected probably represent contaminants (see the Materials and Methods section).

† Smith degradation $\left(\mathrm{IO}_{4}\right)$ was not performed on glycoprotein $\mathrm{S} 2$. 
galactosamine was found in glycoproteins S17 and S14, which had the highest blood-group-A activities. Variable amounts of fucose were detected in these glycoproteins; extracts $\mathrm{S} 1$ and $\mathrm{S} 2$, which had undetectable blood-group- $\mathrm{H}$ activity, contained small amounts of fucose, whereas the largest amounts were found among glycoproteins with strong or moderate blood-group-H activities, with the exception of glycoprotein S11. This latter extract had the highest content of sialic acid, which was generally a minor component in the gastric mucins. Small amounts of mannose and glucose were also detected in these preparations. The glucose was regarded as a contaminant (see the Materials and Methods section).
Effect of one-cycle Smith degradation on sheep gastric mucins (Table 2 and Fig. 1)

After one-cycle Smith degradation the following changes were observed.

(a) Fucose and sialic acid residues were no longer detectable.

(b) Galactose was generally decreased in amount with respect to $N$-acetylglucosamine, consistent with the destruction of terminal or subterminal galactose residues.

(c) Blood-group-A and $-\mathrm{H}$ activities were abolished.

(d) The proportion of $\mathrm{N}$-acetylgalactosamine was not changed in glycoproteins S3, S17, S14 and S11,

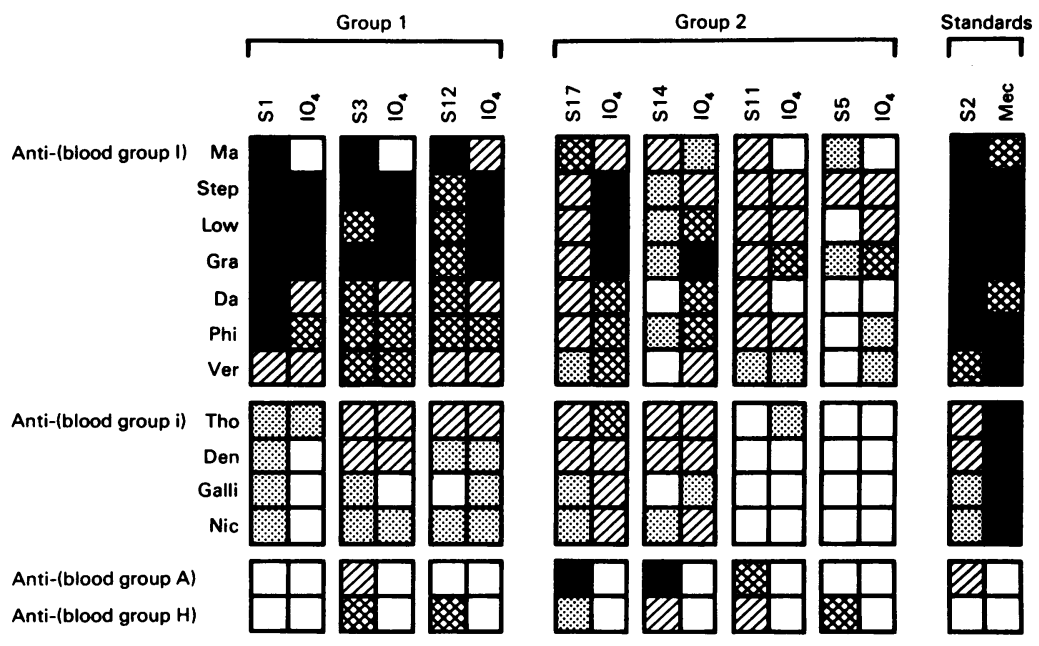

Fig. 1. Blood-group- $\mathrm{I},-\mathrm{i},-\mathrm{A}$ and $-\mathrm{H}$ activities of undegraded and one-cycle-Smith-degraded $\left(\mathrm{IO}_{4}\right)$ sheep stomach glycoproteins

Blood-group-I and -i activities were evaluated by inhibition-of-binding assays with seven anti-(blood group I) and four anti-(blood group i) sera. The results are expressed as the concentration of glycoprotein added that gave 50\% inhibition of binding of the antibodies to a radioiodinated blood-group-I-active sheep gastric glycoprotein, S2, [anti-(blood group I) sera] or a radioiodinated blood-group-Ii-active glycoprotein from human meconium (Mec) [anti-(blood group i) sera]. Blood-group-A and - $\mathrm{H}$ activities were evaluated by haemagglutination-inhibition assays, as described in the text. The results are expressed as the concentration of glycoprotein required to inhibit eight haemagglutinating units.

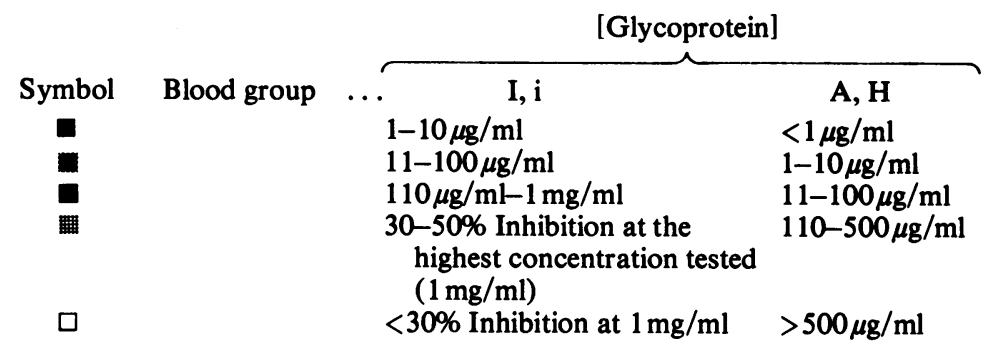


which were originally blood-group-A-active; however, the ratio of this residue to the other monosaccharides was increased in the blood-groupA inactive glycoproteins analysed (S1 and S12). These observations are compatible with destruction of terminal $\mathrm{N}$-acetylgalactosamine residues in bloodgroup A-active oligosaccharide chains and decreased chain length in the oligosaccharide chains (a shortening of chain length in oligosaccharides $\mathrm{O}$-glycosidically linked to protein by $\mathrm{N}$-acetylgalactosamine residues would tend to increase the proportion of $\mathrm{N}$-acetylgalactosamine and would counterbalance the effect of destruction of terminal $\mathrm{N}$-acetylgalactosamine residues).

(e) Glycoproteins in both groups showed much decreased or no reactivity with anti-(blood group I) serum Ma.

$(f)$ On the other hand, the reactivities with the other anti-(blood group I) antibodies were often increased.

(g) The reactivities with anti-(blood group i) sera were mostly comparable with the original material.
Affinity chromatography of sheep gastric mucins with strong blood-group-I activity on an anti-(blood group I) immunoadsorbent column

Of the $22 \mathrm{mg}$ of glycoproteins applied to the anti-(blood group I) adsorbent column, $89 \%$ was recovered: $14 \mathrm{mg}(64 \%)$ was non-retained and $5.5 \mathrm{mg}$ (25\%) was eluted at $37^{\circ} \mathrm{C}$ (Table 3). Radioimmunoassays showed that the non-retained fraction was virtually depleted of inhibitory activities towards anti-(blood group I and i) sera, except anti-(blood group I) serum $\mathrm{Ma}$, whereas the eluted fraction was enriched in its reactivity with all the anti-(blood group I and i) sera (Table 3). No change was detected in the weak blood-group- $\mathrm{A}$ and $-\mathrm{H}$ activities.

Monosaccharide analyses (Table 3) showed that there were lower proportions of fucose, mannose and sialic acid in the eluted fractions relative to the original material and the non-retained fraction.

\section{Discussion}

The present studies have shown that the gastric

Table 3. Analysis of the sheep-gastric-mucin fractions obtained after affinity chromatography on an anti-(blood group I) Low immunoadsorbent

Abbreviation used: SA, sialic acid.

\begin{tabular}{|c|c|c|c|}
\hline & $\begin{array}{l}\text { Original } \\
\text { material }\end{array}$ & $\begin{array}{l}\text { Non-retained } \\
\text { fraction }\end{array}$ & $\begin{array}{l}\text { Eluted } \\
\text { fraction }\end{array}$ \\
\hline \multicolumn{4}{|l|}{ Yields } \\
\hline Dry weight $(\mathrm{mg})$ & 22.0 & 14.0 & 5.5 \\
\hline Carbohydrate $(\mathrm{g} / 100 \mathrm{~g}$ dry wt.) & 79.0 & 78.0 & 75.0 \\
\hline \multicolumn{4}{|c|}{ Carbohydrate analysis ( $\mathrm{nmol}$ of monosaccharide $/ 100 \mathrm{nmol}$ of total carbohydrate) } \\
\hline Fuc & 8.7 & 9.0 & 5.4 \\
\hline Man & 3.0 & 4.2 & 1.0 \\
\hline Glc & 5.1 & 2.4 & 3.4 \\
\hline Gal & 34.0 & 34.4 & 32.8 \\
\hline GlcNAc & 29.9 & 25.8 & 33.2 \\
\hline GalNAc & 16.1 & 18.4 & 21.6 \\
\hline SA & 3.2 & 5.7 & 2.7 \\
\hline \multicolumn{4}{|c|}{ Antigenic analysis [amount giving $50 \%$ inhibition in radioimmunoassays $(\mu \mathrm{g} / \mathrm{ml})$ ] } \\
\hline \multicolumn{4}{|c|}{ Anti-(blood group I) sera } \\
\hline $\mathrm{Ma}$ & 1.7 & 3.0 & 0.4 \\
\hline Step & 10.0 & $>10000$ & 3.0 \\
\hline Low & 3.0 & $>10000$ & 2.0 \\
\hline $\mathrm{Da}$ & 3.8 & $>10000$ & 2.2 \\
\hline Gra & 1.6 & $>10000$ & 1.1 \\
\hline Phi & 2.4 & 2200 & 2.0 \\
\hline Ver & 56.0 & $>10000$ & 28.0 \\
\hline \multicolumn{4}{|l|}{ Anti-(blood group i) sera } \\
\hline Den & 800 & $>10000$ & 200 \\
\hline Nic & 800 & $>10000$ & 600 \\
\hline Tho & 600 & $>10000$ & 90 \\
\hline Galli & 2400 & $>10000$ & 600 \\
\hline \multicolumn{4}{|c|}{ Amount giving haemagglutination-inhibition $(\mu \mathrm{g} / \mathrm{ml})$} \\
\hline Anti-(blood group $\mathrm{H}$ ) serum & 32 & 32 & 32 \\
\hline Anti-(blood group A) serum & 125 & 125 & 125 \\
\hline
\end{tabular}


mucins of sheep express blood-group-I and -i activities. Gastric mucin preparations lacking in blood-group-A and - $\mathrm{H}$ activities had the highest, and those with strong blood-group-A activities had the lowest, blood-group-I activities. The gastric mucins of sheep were shown to differ from those of man in that the majority had precipitating activity with anti-(blood group I) serum Ma irrespective of their blood-group-H (or -A) activities; precipitating blood-group-I (Ma) activity in man is normally confined to gastric mucins of non-secretors lacking in blood-group-A, -B and - $\mathrm{H}$ activities (Picard et al., 1978).

The anti-(blood group I) antibody Low used as immunoadsorbent had previously been shown to require both the Gal $\beta 1 \rightarrow 4 \mathrm{GlcNAc} \beta 1 \rightarrow 6$ - and the Gal $\beta 1 \rightarrow 4$ GlcNAc $\beta 1 \rightarrow 3$ - chains of the branched blood-group-I-active structure for binding to occur (Feizi et al., 1979). The affinity-chromatography experiments showed that, even in glycoproteins with strong blood-group-I-activities, a subpopulation of the macromolecules $(25 \%$ in the preparation studied) expressed the various blood-group-I and -i antigenic determinants. These were retained by anti-(blood group I) serum Low, whereas the majority of macromolecules were non-retained and were lacking in blood-group-I and -i antigenic determinants, except that recognized by anti-(blood group I) serum Ma. These observations, together with the antigenic analyses of individual sheep gastric mucins, suggest that substantial amounts of the blood-group-I (Ma) antigenic determinant, $\mathrm{Gal} \beta 1 \rightarrow 4$ GlcNAc $\beta 1 \rightarrow 6$-, occur in accessible form irrespective of the other types of blood-group-I and -i determinants.

Reactivity with anti-(blood group I) serum Ma was abolished or diminished after one cycle of Smith degradation of glycoproteins in both group 1 and group 2. This indicated that a relatively small proportion of the Ma antigenic determinants occurred in cryptic state. On the other hand, there was evidence for the presence of larger numbers of cryptic antigenic determinants reactive with the other anti-(blood group I) antibodies, and these could be revealed by one cycle of Smith degradation. In particular, the reactivities with anti(blood group I) sera Step, Low and Gra, after degradation of the blood-group-A-active glycoproteins $\mathrm{S} 17$ and S14, were considerably higher than those of similarly degraded blood-group-A- and -B-active human ovarian-cyst glycoproteins (Wood et al., 1979). The blood-group-i activities of the sheep gastric mucins in the present series were less pronounced than their blood-group-I activities (higher blood-group-i activities have been observed in a more recently prepared batch of extracts; E. Wood, E. F. Hounsell \& T. Feizi, unpublished work). Five out of the seven mucins subjected to Smith degradation showed weak or moderate blood-group$i$ activities before and after degradation. These data are compatible with the presence of some exposed and some cryptic oligosaccharide chains with the repeating unbranched sequence $\mathrm{Gal} \beta 1 \rightarrow 4 \mathrm{GlcNAc} \beta 1 \rightarrow 3 \mathrm{Gal} \beta 1 \rightarrow 4 \mathrm{GlcNAc}$ - known to react with anti-(blood group i) cold agglutinins (Niemann et al., 1978).

If anti-(blood group I and i) antibodies indeed only react with type- 2 rather than type- 1 precursor chains, the present studies would suggest that sheep gastric mucins have a higher content of type-2 precursor chains than have human ovarian-cyst glycoproteins. The lack of blood-group-Le $\mathrm{C}^{\mathrm{a}}$ and $-\mathrm{Le}^{\mathrm{b}}$ activities in the sheep gastric mucins may also reflect a lack of type-1 precursor chains; alternatively this may be due to a lack of the Lewis genotype in sheep, as is the case in goats (Marcus \& Grollman, 1966).

The present studies have indicated that sheep gastric mucins are an abundant source of carbohydrate sequences with blood-group-I and -i activities. In more recent studies we have shown that blood-group-Ii-active oligosaccharides can be successfully obtained by preparative-scale enrichment of blood-group-Ii-active glycoproteins followed by alkaline-borohydride degradation (E. Wood, E. F. Hounsell \& T. Feizi, unpublished work).

E. W. and J. L. were holders of Research Studentships and E. F. H. a Post-Doctoral Fellowship from the Medical Research Council.

\section{References}

Bendich, A., Kabat, E. A. \& Bezer, A. E. (1946) J. Exp. Med. 83, 485-497

Bhatti, T., Chambers, R. E. \& Clamp, J. R. (1970) Biochim. Biophys. Acta 222, 339-347

Feizi, T. \& Kabat, E. A. (1972) J. Exp. Med. 135, $1247-1258$

Feizi, T. \& Kabat, E. A. (1974) J. Immunol. 112 , $145-150$

Feizi, T., Kabat, E. A., Vicari, G., Anderson, B. \& Marsh, W. L. J. (1971a). J. Exp. Med. 133, 39-52

Feizi, T., Kabat, E. A., Vicari, G., Anderson, B. \& Marsh, W. L. (1971b) J. Immunol. 106, 1578-1592

Feizi, T., Cederqvist, L. L. \& Childs, R. (1975) Br. J. Haematol. 30, 489-497

Feizi, T., Childs, R. A., Watanabe, K. \& Hakomori, S. (1979) J. Exp. Med. 149, 975-980

Hakomori, S., Stellner, K. \& Watanabe, K. (1972) Biochem. Biophys. Res. Commun. 49, 1061-1068

Hammerström, S., Engvall, E., Johansson, B. G., Svensson, S., Sunblad, G. \& Goldstein, I. J. (1975) Proc. Natl. Acad. Sci. U.S.A. 72, 1528-1532

Hounsell, E. F. (1977) Ph.D. Thesis, University of London

Kabat, E. A. (1970) Blood and Tissue Antigens, p. 190, Academic Press, New York

Lloyd, K. O. \& Kabat, E. A. (1968) Proc. Natl. Acad. Sci. U.S.A. 61, 1470-1477 
Lloyd, K. O., Kabat, E. A. \& Licerio, E. (1968) Biochemistry 7, 2976-2990

Marcus, D. M. \& Grollman, A. P. (1966) J. Immunol. 97, 867-875

Niemann, H., Watanabe, K., Hakomori, S., Childs, R. A. \& Feizi, T. (1978) Biochem. Biophys. Res. Commun. 81, 1286-1293

Picard, J., Waldron Edward, D. \& Feizi, T. (1978) J. Clin. Lab. Immunol. 1, 119-128
Watanabe, K., Hakomori, S., Childs, R. A. \& Feizi, T. (1979) J. Biol. Chem. 254, 3221-3228

Watkins, W. M. (1974) The Red Blood Cells, 2nd edn. (Surgenor, D. M., ed.), p. 293, Academic Press, New York

Wood, E. \& Feizi, T. (1979) FEBS Lett. 104, 135140

Wood, E., Lecomte, J., Childs, R. A. \& Feizi, T. (1979) Mol. Immunol. 16, 813-819 